\title{
Faktor-Faktor yang Mempengaruhi Turnover Intention Karyawan pada PT Permata Prima Canindo di Jakarta
}

\author{
Santi Gunawan dan Kurniati W. Andani \\ Program Studi Manajemen Fakultas Ekonomi \& Bisnis \\ Universitas Tarumanagara \\ Email: santygouww@gmail.com
}

\begin{abstract}
The purpose of this study is to determine and analyze the effect of leadership, job satisfaction and organizational commitment on employee turnover intention at PT Permata Prima Canindo. This research was conducted by the Non Probability Sampling method with the type of purposive sampling. Researchers distributed questionnaires to 95 employees of PT Permata Prima Canindo. Data analysis uses SEM PLS analysis. The results of the analysis concluded that leadership, job satisfaction and organizational commitment influence employee turnover intention at PT Permata Prima Canindo.
\end{abstract}

Keywords: Leadership, job satisfaction, organizational commitment and turnover intention

Abstrak: Tujuan penelitian ini adalah untuk mengetahui dan menganalisa pengaruh kepemimpinan, kepuasan kerja dan komitmen organisasi terhadap turnover intention karyawan pada PT Permata Prima Canindo. Penelitian ini dilakukan dengan metode Non Probability Sampling dengan jenis purposive sampling. Peneliti menyebarkan kuesioner kepada 95 karyawan PT Permata Prima Canindo. Analsisi data menggunakan analisis SEM PLS. Hasil analisis menyimpulkan bahwa kepemimpinan, kepuasan kerja dan komitmen organisasi berpengaruh terhadap turnover intention karyawan pada PT Permata Prima Canindo.

Kata kunci: Kepemimpinan, kepuasan kerja, komitmen organisasi dan turnover intention

\section{LATAR BELAKANG}

Dunia usaha dan organisasi di Indonesia berkembang semakin pesat. Sumber daya manusia merupakan sektor sentral dan penting dalam rangka pencapaian tujuan suatu perusahaan. Setiap organisasi dan perusahaan memiliki berbagai tujuan yang hendak dicapainya. Tujuan tersebut diraih dengan mendayagunakan sumber-sumber yang ada. Dari berbagai sumber daya yang tersedia, satu-satunya yang menjadi fondasi atau asset untuk menunjukan keunggulan kompetitif yang sangat potensial adalah sumber daya manusia.

Sumber daya manusia merupakan asset perusahaan yang sangat vital, karena itu peran dan fungsinya tidak bisa digantikan oleh sumber daya lainnya. Betapapun modern dalam kemajuan teknologi yang digunakan, atau sarana dan prasarananya,seberapa banyak dana yang disiapkan, namun tanpa sumber daya manusia yang profesional semuanya menjadi tidak bermakna. Ditengah persaingan yang kian tajam, peranan departemen sumber daya manusia akan semakin terasa untuk membantu manajer-manajer lini perusahaan untuk mendorong perusahaan dalam mencapai tujuannya. Sumber daya manusia membuat sumber daya lainnya berjalan. Tidak satupun faktor dalam aktifitas bisnis mempunyai dampak yang lebih langsung terhadap kesejahteraan perusahaan selain sumber daya manusia.

Salah satu upaya untuk mencapai target atau tujuan yang diinginkan perusahaan yaitu dengan mencegah atau meminimalisir tingkat turnover intention karyawan dengan 
memperhatikan segala faktor yang menyebabkan keinginan karyawan untuk berpindah disikapi dengan sebuah keadaan dimana karyawan mulai merasakan atau mendapati kondisi kerja yang terasa sudah tidak sesuai dengan apa yang diharapkan.

Keinginan untuk keluar dari pekerjaan (Turnover intention) menjadi problematika di ruang lingkup perusahaan. Turnover intention pada dasarnya adalah keinginan karyawan untuk keluar dari satu tempat kerja ke tempat kerja yang lain, namun belum sampai pada tahap realisasi yaitu perpindahan kerja dari satu tempat ke tempat lainnya. Intensi keluar (turnover intention) diartikan sebagai kadar atau tingkat niat tenaga kerja keluar dari perusahaan, turnover mengarah pada kenyataan akhir yang dihadapi perusahaan berupa jumlah karyawan yang meninggalkan perusahaaan pada, periode tertentu. Turnover dapat berupa pengunduran diri, perpindahan keluar unit perusahaan, pemberhentian atau kematian anggota perusahaan (Witasari, 2009). Menurut Zeffane (dalam Putriani, 2014:30) turnover intention adalah kecenderungan atau niat karyawan untuk berhenti bekerja dari pekerjaannya secara sukarela menurut pilihannya sendiri. Banyak faktor yang mempengaruhi turnover intention dari perusahaan terhadap karyawan diantaranya adalah kepemimpinan, kepuasan kerja dan komitmen organisasional (Sobirin, dkk 2016). Salah satu yang mempengaruhi turnover intention karyawan adalah kepemimpinan yang dimiliki oleh pimpinan perusahaan. Kepemimpinan merupakan sifat penting pimpinan dalam pengorganisasian sumber daya manusia yang baik. Pimpinan dan kepemimpinan yang diembannya memiliki fungsi strategis yang menentukan kinerja sumber daya manusia. Pemimpin yang melaksanakan kepemimpinannya secara efektif, dapat menggerakan orang/personil ke arah tujuan yang dicita-citakan, akan menjadi panutan dan teladan. Sebaliknya pemimpin yang keberadaannya hanya sebagai figur dan tidak memiliki pengaruh serta kemampuan kepemimpinan, akan mengakibatkan kinerja sumber daya manusia menjadi lambat, karena tidak memiliki kapabilitas dan keakapan untuk menghasilkan kinerja yang baik.

Selain kepemimpinan, kepuasan kerja yang dirasakan oleh karyawan juga dapat mempengaruhi turnover intention (Heriawan dan Atmawajati, 2018). Kepuasan Kerja adalah keadaan emosi yang senang atau emosi positif yang berasal dari penilaian pekerjaan atau pengalaman kerja seseorang (Luthans, 2006:243). Kepuasan kerja mempunyai arti penting untuk aktualisasi diri karyawan. Karyawan yang tidak mendapatkan kepuasan kerja tidak akan mencapai kematangan psikologis. Karyawan yang mendapatkan kepuasan kerja yang baik biasanya mempunyai catatan kehadiran, perputaran kerja dan prestasi kerja yang baik dibandingkan dengan karyawan yang tidak mendapatkan kepuasan kerja. Ketidakpuasan dalam bekerja dapat menimbulkan perilaku agresif, atau sebaliknya akan menunjukan sikap menarik diri dari kontak dengan lingkungan sosialnya. Misalnya dengan mengambil sikap berhenti dari perusahaan, suka bolos, dan perilaku lain yang cenderung bersifat menghindari dari aktivitas organisasi.

Selain kepemimpinan dan kepuasan kerja, komitmen organisasi juga dapat mempengaruhi turnover intention pada karyawan (Shobirin, dkk 2016). Yusuf dan Syarif (2018:32) mendefinisikan komitmen organisasi adalah sebagai sikap loyalitas karyawan terhadap organisasi, dengan cara tetap bertahan dalam organisasi, membantu mencapai tujuan organisasi dan tidak memiliki keinginanuntuk meninggalkan organisasi dengan alasan apapun. Komitmen seseorang terhadap organisai dan tujuannya merupakan salah satu alasan seseorang untuk tetap bertahan. Dan jika komitmen karyawan tinggi maka sedikit alasan untuk tidak bergabung dengan organisasi yang dipilihnya dalam waktu lama. Bila tingkat komitmen meningkat, maka transisi peran dapat terjadi dan individu mendapatkan keanggotaannya kembali pada kelompok secara penuh, namun bila komitmen tidak dicapai maka individu akan melakukan transisi peran dengan cara keluar kelompok (Sutrisno, 2010). Penelitian yang dilakukan Abadi, dkk (2016) menyimpulkan bahwa komitmen organisasi berpengaruh terhadap turnover intention karyawan. Kemudian penelitian yang dilakukan 
Shobirin, dkk (2016) juga menyimpulkan bahwa komitmen organisasi berpengaruh terhadap turnover intention.

\section{KAJIAN TEORI}

Menurut Mobley (2011:15) mendefinisikan "turnover intention adalah hasil evaluasi individu mengenai kelanjutan hubungannya dengan perusahaan dimana dia bekerja namum belum diwujudkan dalam tindakan nyata". Sedangkan menurut Robbins dan Judge (2015:214) mendefinisikan : "Turnover intention adalah kecenderungan atau tingkat dimana seorang karyawan memiliki kemungkinan untuk meninggalkan perusahaan baik secara sukarela maupun tidak sukarela yang disebabkan karena kurang menariknya pekerjaan saat inni dan tersedianya alternative pekerjaan lain." Menurut Zahara (2016:34) menyatakan bahwa "turnover intention sebagai hasrat keinginan untuk mencari peluang kerja alternatif pada organisasi atau perusahaan lain."

Menurut Yukl (2014:18) berpendapat bahwa, "Leadership is reflect the assumption that it involves a process whereby intentional influence is exerted over other people to guide, structure, and facilitate activities and relationships in a group or organization." Hal tersebut menyatakan bahwa kepemimpinan adalah proses yang disengaja dari seseorang untuk menekankan pengaruhnya yang kuat terhadap orang lain guna membimbing, membuat struktur, serta memfasilitasi aktivitas dan hubungan di dalam grup atau organisasi. Pendapat lain dikemukakan oleh Rivai (2013:234) yang menyatakan bahwa "kepemimpinan adalah proses mengarahkan dan mempengaruhi aktivitas-aktivitas yang ada hubungannya dengan pekerjaan para anggota kelompok." Menurut Armstrong (2016:4) menyatakan bahwa, "Leadership is the process of getting people to do their best to achieve a desired result." Hal tersebut menyatakan bahwa, kepemimpinan adalah proses membuat orang melakukan yang terbaik untuk mencapai hasil yang diinginkan. Kemudian menurut Schermerhorn (2013:352) mendefinisikan "Leadership is the process of inspiring others to work to accomplish important takss." Hal tersebut menyatakan bahwa, kepemimpinan adalah proses menginspirasi orang lain untuk bekerja keras guna menyelesaikan tugas-tugas penting.

Menurut Robbins (2017:118) menyatakan bahwa, "Job satisfaction a positive feeling about a job resulting from an evaluation of its characteristics is clearly broad." Hal tersebut menyatakan bahwa kepuasan kerja adalah perasaan positif tentang pekerjaan yang dihasilkan dari evaluasi karakteristiknya yang luas. Kemudian Suparyadi (2015:437) mendefinisikan "kepuasan kerja sebagai suatu yang positif yang didasarkan pada hasil evaluasi terhadap apa yang diharapkan akan diperoleh melalui upaya-upaya yang dilakukan dalam melaksanakan suatu pekerjaan dengan hasil atau ganjaran yang diterimanya." Sementara itu, menurut Rivai (2014:620) menyatakan bahwa "kepuasan kerja merupakan evaluasi yang menggambarkan seseorang atas perasaan sikapnya senang atau tidak senang, puas atau tidak puas dalam bekerja."

Menurut Colquitt (2014:64) menyatakan bahwa : "Organizational commitment is defined as the desire on the part of an employee to remain a member of the organization.Organizational commitment influences whether an employee stays a member of the organization or leaves to pursue another job." Hal di atas menyatakan bahwa, komitmen organisasi didefinisikan sebagai keinginan dari pihak karyawan untuk tetap menjadi anggota organisasi. Komitmen organisasional mempengaruhi apakah seorang karyawan tetap menjadi anggota organisasi atau pergi untuk mengejar pekerjaan lain. Pendapat lain dikemukan oleh Griffin (2014:75) bahwa, "Organizational Commitment is a person's identification with and attachment to an organization." Hal tersebut menyatakan bahwa komitmen organisasi adalah suatu identifikasi dan keterikatan dari seseorang dengan suatu organisasi. Sedangkan menurut Gibson yang dikutip oleh Wibowo (2017:430) memberikan pengertian komitmen 
organisasi sebagai perasaan identifikasi, loyalitas, dan pelibatan dinyatakan oleh pekerja terhadap organisasi atau unit dalam organisasi.

Pengaruh Kepemimpinan Terhadap Turnover intention. Peran seorang pemimpin yang secara tidak langsung maupun langsung berkontribusi terhadap perubahan-perubahan yang terjadi dalam organisasi atau perusahaan. Seorang pemimpin akan sangat peduli pada aspek kepuasan kerja, karena mempunyai tanggung jawab moral apakah dapat memberikan lingkungan yang memuaskan pada karyawan atau tidak. Kepemimpinan memberikan dampak langsung pada emosional dan produktifitas karyawan, pimpinan dapat membuat karyawan menjadi tidak nyaman dengan cara yang berbeda misalnya dengan terlalu mengontrol, terlalu curiga, kurang memahami kondisi di lapangan, terlalu banyak memperintah dan salah dalam pengambilan keputusan. Hal tersebut akan membuat karyawan berkeinginan untuk meninggalkan perusahaan. Menurut Gary Yukl (2014:18) mengemukakan bahwa kepemimpinan adalah proses yang disengaja dari seseorang untuk menekankan pengaruhnya yang kuat terhadap orang lain guna membimbing, membuat struktur, serta memfasilitasi aktivitas dan hubungan di dalam grup atau organisasi.

Hasil penelitian yang dilakukan oleh Abadi, dkk (2016) terbukti bahwa kepemimpinan berpengaruh terhadap turnover intention karyawan. Wulandari Shobirin, dkk (2016) dalam penelitiannya juga menyebutkan bahwa kepemimpinan berpengaruh terhadap turnover intention. Dengan demikian dapat ditarik kesimpulan bahwa kepemimpinan berpengaruh terhadap turnover intention.

Pengaruh Kepuasan Kerja Terhadap Turnover intention. Kepuasan kerja karyawan memiliki arti penting bagi perusahaan. Karyawan yang merasa puas pastinya akan memutuskan untuk tetap bertahan di perusahaan tempat dia bekerja dan mampu bekerja secara produktif. Ketidakpuasan kerja sering didefinisikan sebagai suatu alasan yang menyebabkan karyawan meninggalkan pekerjannya. Novliadi dikutip oleh Sunariani (2016) mengemukakan bahwa kepuasan kerja memiliki hubungan erat terhadap pikiran untuk berhenti kerja dan memiliki keinginan untuk mencari pekerjaan lain. Menurut Robbins (2017:118) menyatakan bahwa kepuasan kerja adalah perasaan positif tentang pekerjaan yang dihasilkan dari evaluasi karakteristiknya yang luas.

Hasil penelitian yang telah dilakukan oleh Hariawan dan Atmajawati (2018) terbukti bahwa kepuasan kerja memiliki pengaruh terhadap turnover intention karyawan. Kemudian $\mathrm{Li}$, et.al (2018) juga melakukan penelitian dengan hasil yang menyatakan bahwa kepuasan kerja memiliki pengaruh terhadap turnover intention karyawan. Dengan demikian, berdasarkan hasil penelitian yang telah dilakukan penulis dapat menarik kesimpulan bahwa kepuasan kerja memiliki pengaruh terhadap turnover intention karyawan.

Pengaruh Komitmen Organisasi Terhadap Turnover intention. Komitmen organisasi merupakan faktor penting bagi perusahaan. Perusahaan memerlukan karyawan yang memiliki komitmen terhadap organisasinya. Karyawan yang memiliki tingkat komitmen yang tinggi cenderung akan loyal kepada organisasi atau perusahaan. Hal tersebut tentunya sangat menguntungkan bagi perusahaan, karena karyawan adalah sumber daya manusia terpenting yang harus perusahaan pertahankan. Sebaliknya, jika karyawan memiliki komitmen yang rendah maka loyalitas mereka terhadap perusahaan pun akan rendah. Pada saat loyalitas rendah maka disitulah akan muncul pikiran karyawan untuk meninggalkan perusahaan dan mencari perusahaan lain yang dirasa lebih menguntungkan bagi dirinya. Menurut Colquitt (2014:64), komitmen organisasi didefinisikan sebagai keinginan dari pihak karyawan untuk tetap menjadi anggota organisasi. Komitmen organisasional mempengaruhi apakah seorang karyawan tetap menjadi anggota organisasi atau pergi untuk mengejar pekerjaan lain. 
Hasil penelitian yang dilakukan oleh Peachey, et al (2013) menyatakan bahwa komitemn organisasi memiliki pengaruh terhadap turnover intention. Hal sedana juga dinyatakan oleh Gatling, et al (2014) dalam penelitiannya yang menyebutkan bahwa komitmen organisasi memiliki pengaruh terhadap turnover intention. Hasil penelitian tersebut penulis dapat menarik kesimpulan bahwa komitmen organisasi berpengaruh terhadap turnover intention karyawan.

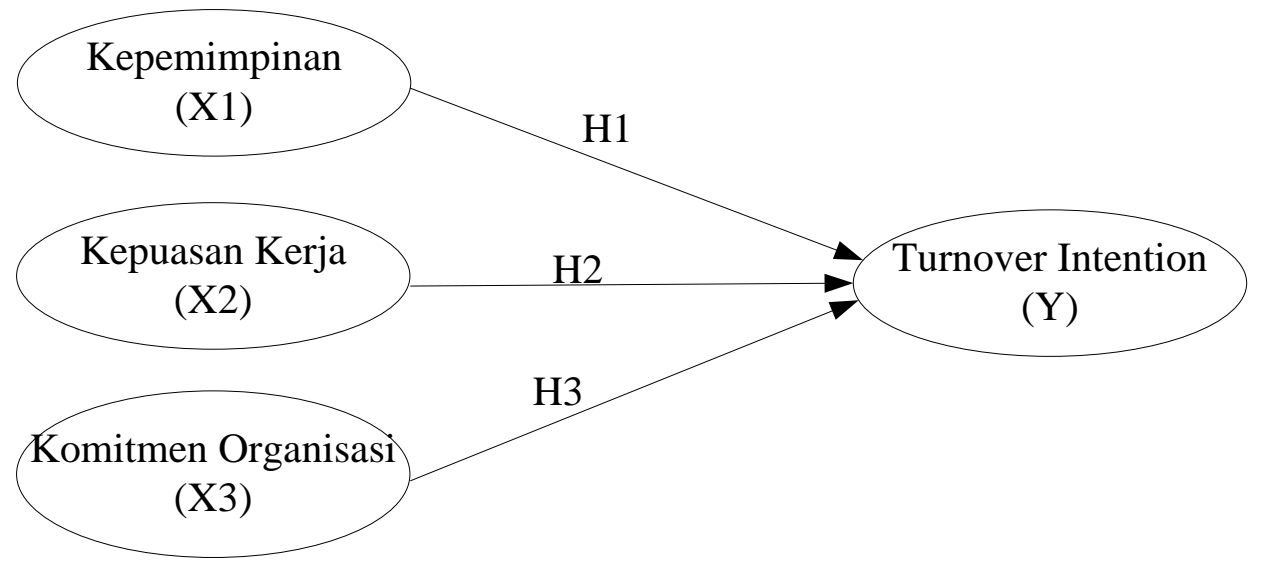

Gambar 1. Kerangka Pemikiran

Berdasarkan kerangka pemikiran diatas maka hipotesis penelitian ini adalah sebagai berikut:

H1: Terdapat pengaruh yang signifikan kepemimpinan terhadap turnover intention.

$\mathrm{H} 2$ : Terdapat pengaruh yang signifikan kepuasan kerja terhadap turnover intention .

H3: Terdapat pengaruh yang signifikan komitmen organisasi terhadap turnover intention.

\section{METODE PENELITIAN}

Dalam penelitian ini, peneliti menggunakan desain penelitian kausal. Desain penelitian kausal bertujuan untuk menganalisis kemungkinan hubungan sebab akibat, namun tidak dengan suatu eksperimen tetapi dilakukan dengan cara pengamatan terhadap data dari faktor yang di identifikasi menjadi penyebab dan sebagai pembanding. Populasi dalam penelitian ini adalah seluruh karyawan PT Permata Prima Canindo sebanyak 125 karyawan Pengambilan sampel diambil dengan menggunakan metode jenis purposive sampling, karena didalam menentukan sampel ada pertimbangan kriteria tertentu. Jumlah sampel sebanyak 95 responden.

Data dianalisis menggunakan PLS-SEM dimana data diolah dengan program software SmartPLS 3. Pertama, pengolahan dilakukan pada outer model untuk menguji validitas (konvergen dan diskriminan) dan reliabilitas. Uji validitas konvergen dilihat dari nilai outer loadings di antara 0,5-0,7 kemudian AVE > 0,5. Selanjutnya untuk uji validitas diskriminan, beracuan pada Fornell-Larcker Criterion dan Cross Loadings (Garson, 2016). Kemudian pada analisis reliabilitas, beracuan pada nilai cronbach's alpha dan composite reliability > 0,7 (Ghozali dan Latan, 2015:75).

Kedua, pengolahan dilakukan pada inner model untuk menguji hipotesis yang telah dihasilkan. Sebelum pengujian hipotesis, pertama dilakukan pengujian hubungan antar konstruk dengan melihat nilai R-square $\left(\mathrm{R}^{2}\right)$ dengan kriteria $(1-0,75)$ "bersifat kuat", $(0,74$ - 0,5) "bersifat moderat", dan $(0,49$ - 0,25) "bersifat lemah" (Ghozali dan Latan, 2015:78), nilai Q-square $\left(\mathrm{Q}^{2}\right)$ dengan kriteria $\mathrm{Q}^{2}>0$ "memiliki kemampuan prediksi" (Chin, 2010), dan nilai GoF (Goodness of Fit) dengan kriteria 0,1 "kelayakan model kecil", 0,25 "kelayakan 
model sedang", dan 0,36 "kelayakan model besar" (Tenenhaus, 2005). Selanjutnya pengujian hipotesis, untuk melihat pengaruh yang terjadi lihat (positif/ negatif) dari coefficient yang dihasilkan, dan menggunakan $t$-statistics $>1,645$ (hipotesis tidak ditolak) dan $p$-values $<0,05$ (hipotesis signifikan) (Haryono, 2017:40).

\section{HASIL UJI STATISTIK}

\section{Hasil Uji validitas}

Pada hasil validitas konvergen, didapatkan semua angka $>0,5$ pada nilai outer loadings untuk setiap pernyataannya, dan didapatkan semua angka $>0,5$ pada nilai Average Variance Extracted / AVE maka pernyataan yang digunakan sudah valid secara validitas konvergen. Selain itu, pada hasil validitas diskriminan, peneliti menggunakan nilai Cross Loadings dimana nilai korelasi antara pernyataan terhadap variabel nya sendiri harus lebih besar daripada pernyataan terhadap variabel lainnya berdasarkan hasil kalkulasi SmartPLS 3, didapatkan semua angka pada pernyataan terhadap variabel-nya sendiri lebih besar daripada terhadap variabel lainnya maka pernyataan sudah valid secara validitas diskriminan.

\section{Hasil Uji reliabilitas}

Pada hasil reliabilitas, maka berdasarkan hasil yang dikalkulasi oleh program SmartPLS 3, didapatkan semua angka pada nilai Cronbach's Alpha untuk setiap pernyataannya adalah $>0,7$ dan pada nilai Composite Reliability didapatkan semua angka untuk setiap pernyataannya adalah $>0,7$. Maka pernyataan yang digunakan dalam penelitian ini sudah reliabel berdasarkan kedua nilai reliabilitas, yakni Cronbach's Alpha dan Composite Reliability.

\section{Hasil Uji R-Square $\left(\mathbf{R}^{2}\right)$ dan GoF (Goodness of Fit)}

Uji R-square $\left(\mathrm{R}^{2}\right)$ yang dihasilkan sebesar 0,768 (bersifat kuat) pada variabel "turnover intention" Maka dapat disimpulkan bahwa sebesar $76,8 \%$ variabel turnoer intention dipengaruhi oleh ketiga variabel variabel independen yang digunakan dalam penelitian ini, yakni kepemimpinan, kepuasan kerja dan komitmen organisasi.. Kemudian sisanya sebesar 23,2\% variabel turnover intention dipengaruhi oleh variabel lain diluar variabel penelitian ini. Kemudian untuk Hasil uji GoF, didapatkan nilai GoF sebesar 0,585 yang berarti bahwa keseluruhan dalam kinerja model prediksi yang ditinjau pada tingkat kesesuaian antara inner model dengan outer model adalah besar karena di atas 0,36 .

\section{Hasil Uji Hipotesis}

Tabel 1. Hasil Uji Hipotesis (Bootstrapping)

\begin{tabular}{|l|r|r|r|r|r|}
\hline & $\begin{array}{l}\text { Original } \\
\text { Sample }(O)\end{array}$ & $\begin{array}{l}\text { Sample } \\
\text { Mean }(M)\end{array}$ & $\begin{array}{l}\text { Standar } \\
\text { Deviation } \\
\text { (STDEV) }\end{array}$ & $\begin{array}{l}\text { T Statistics } \\
(\text { JO/STDEV })\end{array}$ & \begin{tabular}{l} 
Value \\
\hline $\begin{array}{l}\text { Kepemimpinan } \rightarrow \\
\text { turnover intention }\end{array}$
\end{tabular} \\
\hline $\begin{array}{l}\text { Kepuasan kerja } \rightarrow \\
\text { turnover intention }\end{array}$ & -0.394 & 0.392 & 0.109 & -3.609 & 0.000 \\
\hline $\begin{array}{l}\text { Komitmen organisasi } \rightarrow \\
\text { turnover intention }\end{array}$ & -0.185 & 0.196 & 0.092 & -2.009 & 0.045 \\
\hline
\end{tabular}

Sumber: Hasil Olah Data pada SmartPLS3 


\section{Diskusi}

Hipotesis yang pertama menunjukkan bahwa variabel kepemimpinan terbukti berpengaruh negatif signifikan terhadap turnover intention karena hasil dari nilai t-statistik motivasi sebesar -3,609 yang berarti lebih besar dari 1,96 dan p-values kepemimpinan sebesar 0,000 yang berarti lebih kecil dari 0,05. Sehingga dapat disimpulkan bahwa kepemimpinan memiliki pengaruh negatif yang signifikan terhadap turnover intention. Hal tersebut sesuai dengan penelitian yang telah dilakukan Abadi, dkk (2016) dan Shobirin, dkk (2016) yang menyatakan kepemimpinan berpengaruh negatif terhadap turnover intention. Kepemimpinan memegang peran penting dalam roda perputaran organisasi. Pemimpin harus mampu membawa organisasi berkembang dan mencapai tujuan yang telah direncanakan. Seluruh struktur yang berada di organisasi dinaungi oleh pemimpin, sehingga tanggung jawab pemimpin begitu besar. Kepemimpinan mempunyai andil dalam mempertahankan karyawannya. Seorang pemimpin bisa menjadi salah satu faktor karyawan untuk keluar apabila karyawan merasa diperlakukan dengan tidak baik, komunikasi tidak berjalan dengan semestinya, dan pemimpin yang tidak memberi contoh yang baik terhadap karyawan.

Untuk hipotesis kedua, dapat disimpulkan kepuasan kerja memiliki pengaruh negatif dan signifikan terhadap turnover intention dengan tingkat keyakinan 95\%, karena hasil dari nilai t-statistik kepuasan kerja sebesar -3,559 yang berarti lebih besar dari 1,96 dan p-values culture sebesar 0,000 yang berarti lebih kecil dari 0,05. Hasil penelitian ini sejalan dengan penelitian Hariawan dan Atmajawati (2018) serta penelitian Li, et.al (2018) yang menyatakan bahwa kepuasan kerja memiliki pengaruh terhadap turnover intention karyawan. Kepuasan kerja merupakan hal yang cukup penting untuk seorang karyawan. Faktor penentu kepuasan kerja pun ada berbagai macam yaitu dengan memberikan kenyamanan melalui lingkungan kerjanya, adanya promosi untuk meningkatkan pangkat atau kedudukan pun,gaji/upah yang didapatkan oleh karyawan dan sebagainya. Ketidakpuasan dalam bekerja dapat menimbulkan perilaku agresif, atau sebaliknya akan menunjukan sikap menarik diri dari kontak dengan lingkungan sosialnya. Misalnya dengan mengambil sikap berhenti dari perusahaan, suka bolos, dan perilaku lain yang cenderung bersifat menghindari dari aktivitas organisasi. Dimana karyawan yang merasa puas dalam bekerja memiliki intensi keluar yang rendah dan sebaliknyakaryawan yang merasa tidak puas dalam bekerja memiliki intensi keluar yang tinggi. Jadi dapat disimpulkan kepuasan kerja berhubungan secara negatif dengan turnover intention.. Individu yang merasa terpuaskan dengan pekerjaannya cenderung untuk bertahan dalam organisasi. Sedangkan individu yang merasa kurang terpuaskan dengan pekerjaannya akan memilih keluar dari organisasi.

Kemudian untuk hipotesis ketiga menunjukkan bahwa variabel komitmen organisasi terbukti berpengaruh negatif dan signifikan terhadap turnover intentiojn karena hasil dari nilai t-statistik kepuasan kerja sebesar -2.009 yang berarti lebih besar dari 1,96 dan p-values sebesar 0,045 yang berarti lebih kecil dari 0,05. Sehingga dapat disimpulkan bahwa komitmen organisasi memiliki pengaruh negatif dan signifikan terhadap turnover intention. Hal tersebut sesuai dengan penelitian yang telah dilakukan Peachey, et al (2013), Gatling, et al (2014) dan Abadi, dkk (2016) yang menyatakan bahwa variabel komitmen organisasi berpengaruh negatif dan signifikan terhadap turnover intention. Komitmen organisasi merupakan faktor penting bagi perusahaan. Perusahaan memerlukan karyawan yang memiliki komitmen terhadap organisasinya. Karyawan yang memiliki tingkat komitmen yang tinggi cenderung akan loyal kepada organisasi atau perusahaan. Hal tersebut tentunya sangat menguntungkan bagi perusahaan, karena karyawan adalah sumber daya manusia terpenting yang harus perusahaan pertahankan. Sebaliknya, jika karyawan memiliki komitmen yang rendah maka loyalitas mereka terhadap perusahaan pun akan rendah. Pada saat loyalitas rendah maka disitulah akan muncul pikiran karyawan untuk meninggalkan perusahaan dan mencari perusahaan lain yang dirasa lebih menguntungkan bagi dirinya 


\section{KESIMPULAN}

Berdasarkan penelitian dan pembahasan, maka dapat diambil beberapa kesimpulan sebagai berikut:

1. Terdapat pengaruh negatif dan signifikan antara kepemimpinan terhadap turnover intention karyawan pada PT Permata Prima Canindo di Jakarta. Artinya, semakin baik pemimpin suatu perusahaan semakin rendah tingkat turnover intention karyawan.

2. Terdapat pengaruh negatif dan signifikan antara kepuasan kera terhadap turnover intention PT Permata Prima Canindo di Jakarta. Maksudnya semakin tinggi kepeuasan kerja yang di rasakan karyawan terhadap perusahaan akan semakin rendah tingkat turnover intention karyawan.

3. Terdapat pengaruh negatif dan signifikan komitmen organisasi terhadap turnover intention PT Permata Prima Canindo di Jakarta. Artinya, semakin setia karyawan terhadap perusahaan semakin rendah tigkat turnover intention karyawan.

Setelah meneliti dan mengetahui permasalahan yang ada di PT Permata Prima Canindo, maka saran yang dapat diberikan bagi perusahaan dan bagi peneliti lain yaitu:

1. Disarankan dalam upaya meningkatkan Kepemimpinan karyawan. PT Permata Prima Canindo, dapat dilakukan dengan cara memperhatikan cara manajer dalam memimpin atau memotivasi para bawahanya dalam melakukan setiap pekerjaan yang mereka lakukan agar Turnover intention karyawan dapat ditekan, sehingga tujuan perusahaan dapat tercapai.

2. Disarankan dalam upaya meningkatkan Kepuasan kerja karyawan . PT Permata Prima Canindo, dapat dilakukan dengan cara memperhatikan kepuasan gaji karyawan, kepuasan promosi karyawan dan kepuasan karyawan dengan rekan sekerja atau dengan cara lebih mengarahkan karyawan dalam pemecahan masalah secara cermat dan memberi dukungan pengamanan lebih untuk karyawan dalam melaksanakan pekerjaannya. Sehingga karyawan merasa puas bekerja dan memiliki komitmen dalam perusahaan sehingga tidak ada niatan untuk keluar dariperusahaan.

3. Disarankan dalam upaya meningkatkan Komitmen Organisasional yang diberikan oleh PT Permata Prima Canindo dapat dilakukan dengan cara memperhatiakan komitmen afektif seperti karyawan akan sangat bahagia menghabiskan sisa karier di perusahaan dia bekerja, komitmen berkesinambungan seperti akan sangat merugikan bagi karyawan apabila meninggalkan perusahaan dan komitmen normatif seperti jika karyawan memperoleh tawaran pekerjaan yang lebih baik, karyawan tidak akan meninggalkan perusahaan, agar Turnover intention karyawan PT Permata Prima Canindo dapat ditekan, sehingga tujuan perusahaan dapat tercapai.

4. Bagi peneliti lain, disarankan untuk melakukan penambahan variabel lain yang juga diperkirakan dapat memberikan pengaruh terhadap turnover intention seperti stres kerja, beban kerja, dan motivasi kerja.

\section{DAFTAR PUSTAKA}

Abadi, Tomi Kurnia, Ice Kamela dan Surya Dharma (2016) Pengaruh Kepuasan Kerja, Komitmen Organisasional Dan Kepemimpinan Terhadap Turnover Intention Pada Karyawan PT.Pancaran Sinar Mandiri Padang. Jurnal Riset Manajemen. Vol 4 No. $1: 1-13$ 
Abouraia1, Mahmoud Kamal and Othman, Saad Mohammed (2017) Transformational Leadership, Job Satisfaction, Organizational Commitment, and Turnover Intentions: The Direct Effects among Bank Representatives. American Journal of Industrial and Business Management. Vol.7, No. 2: 404-423

Armstrong, Michael. (2016). Armstrong's Handbook of Management and Leadership for HR, 4th ed. Philadelphia: Kogan Page Limited.

Colquitt, Jason A. (2014). Organizational Behavior - Improving performance and commitment. Edition 4. MC Graw - Hill Education

Fattah, Hussein (2017). Kepuasan Kerja dan Kinerja Pegawai: Budaya Organisasi, Perilaku Pemimpin dan Efikasi Diri. Yogyakarta: Elmatera

Griffin, Ricky W. (2014). Organizational Behavior : Managing people and organizations. Edition 11. South-Western, Cengage Learning

Li, Liang, Yongyue Zhu and Chanwook Park (2018) Leader-Member Exchange, Sales Performance, Job Satisfaction, And Organizational Commitment Affect Turnover Intention. Social Behavior and Personality, Vol. 46 No. 11: 1909-1922

Luthans, Fred (2006), Perilaku Organisasi. Edisi Sepuluh. Yogyakarta: Andi

Mawardi (2016) Analisis Pengaruh Komitmen Organisasi Dan Kepuasan Kerja Terhadap Turnover Intention Karyawan Dealer Honda CV. Semoga Jayacabang Tenggarong.JEMI . Vol 16. No 2: 31-45

Mobley, William H. (2011). Pergantian Karyawan Sebab Akibat dan Pengendaliannya. Jakarta: PPM dan Bisnis

Peachey, Jon Welty, Laura J. Burton and Janelle E. Wells (2013) Examining the influence of transformational leadership, organizational commitment, job embeddedness, and job search behaviors on turnover intentions in intercollegiate athletics. Leadership \& Organization Development Journal. Vol. 35 No. 8: 740-755

Putriani, Arin Dewi. (2014). Pengaruh Kompensasi dan Motivasi Kerja Terhadap Turnover Intention. Jurnal Ilmu Manajemen. Vol. 1, No 2: 25-45

Rivai, Veithzal. (2013). Manajemen sumber daya manusia untuk perusahaan. Jakarta: Raja Grafindo Persada

Robbins, Stephen P (2017) Organizational Behavior. Edition 17. Pearson Education Limited.

Robbins, Stephen P and Judge, Timothy A. (2015). Perilaku Organisasi. Edisi Keenam belas. Jakarta: Salemba Empat.

Saklit, I Wayan (2017) Pengaruh Gaya Kepemimpinan Dan Pengembangan Karir Terhadap Intensi Turnover: Kepuasan Kerja Sebagai Mediator. Jurnal Manajemen. Vol XXI, No. 03: 472-490

Schermerhorn, John R. (2013). Management, 12th ed. New Jersey: John Willey \& Sons Inc.

Shobirin, Muhamad, Maria M. Minarsih, dan Azis Fathoni (2016) Analisis Pengaruh Kepemimpinan, Komitmen Organisasi Dan Kepuasan Kerja Terhadap Keinginan Pindah Kerja Karyawan PT. Bank BTPN Mitra Usaha Rakyat Area Semarang. Journal of Management. Vol.02 No.02, Hal. 1-18.

Sunariani, Ni Nyoman. (2016). Peran Kepemimpinan, Komitmen Organisasi, Turnover Intention, Kepuasan Kerja dan Kinerja Karyawan LPD Desa Adat Tanjung BenoaBadung. Jurnal Manajemen dan Bisnis. Vol.13, No.3, 124-128.

Suparyadi. (2015). Manajemen Sumber Daya Manusia. Edisi Kesatu. Yogyakarta: Andi Offset.

Sutrisno. Edy (2010). Manajemen Sumber Daya Manusia. Edisi Pertama. Cetakan Pertama. Jakarta : Kencana

Uce, Indahyanti. (2013). Penulisan karya ilmiah, panduan awal menyusun skripsi dan tugas akhir. Jakarta : Salemba Empa 
Yukl, Gary. (2014). Leadership in organizations. Edition 8. England : Pearson Education Limited.

Yusuf, Ria Mardiana dan Syarif Darman (2018) Komitmen Organisasi: Definisi, Pengaruh, Mempengaruhi. Makasar: Nas Media Pustaka

Zahara, Tussoleha Rony. (2016). Siapa Harus Pergi Siapa Harus Tinggal: Strategi Mencegah Turnover Intention Gen-Y. Edisi pertama. Jakarta: Pusat Studi Manajemen Sumber Daya Manusia 